Cumhuriyet Üniversitesi Fen Fakültesi Fen Bilimleri Dergisi (CFD), Cilt 37, No. 1 (2016) ISSN: 1300-1949
Cumhuriyet University Faculty of Science Science Journal (CSJ), Vol. 37, No. 1 (2016) ISSN: 1300-1949

http://dx.doi.org/10.17776/csj.38701

\title{
Some Transition Metal Complexes of NO Type Schiff Base: Preparation and Characterization
}

\author{
Erdal CANPOLAT ${ }^{1 *}$, Ayşe AĞLAMIŞ², Hakan ŞAHAL ${ }^{2}$, Mehmet KAYA $^{2}$ \\ I, Department of Elementary Science Education, Faculty of Education, Firat University, 23119, Elazı̆̆, Turkey \\ ${ }^{2}$ Department of Chemistry, Faculty of Sciences, Firat University, 23119, Elazlğ, Turkey
}

Received: 25.08.2014; Accepted: 17.01.2016

\begin{abstract}
Metal complexes of Schiff base ligand (5-bromo-3-methoxysalicyliden-p-iminoacetophenone oxime) derived from 5-bromo-3-methoxsalicylaldehyde and p-aminoacetophenoneoxime is reported. Schiff base was found to be bidentate ligand involving the imino nitrogen and carboxyl oxygen atoms in the complexes. Metal to ligand ratio were found to be 1:2 for all of the complexes. $\mathrm{Co}(\mathrm{II}), \mathrm{Ni}$ (II), and $\mathrm{Zn}$ (II) complexes have been found tetrahedral geometry and $\mathrm{Cu}$ (II) complex has been found four coordinated geometry. The complexes are found to have the formulae [M(L)2]. The compounds obtained have been characterized by their elemental analyses, IR, 1H-NMR, 13C-NMR, UV spectra, magnetic susceptibility and thermogravimetric analyses (TGA).
\end{abstract}

Keywords: Schiff base, transition metal complexes

\section{N,O Tipi Schiff Bazının Bazı Geçiş Metal Kompleksleri: Hazırlanması ve Karakterizasyonu}

\begin{abstract}
Özet. Bu çalışmada, 5-brom-3-metoksi salisilaldehit ve p-aminoasetofenon oksimden türetilmiş Schiff bazı ligandı (5-brom-3metoksisalisiliden-p-iminoasetofenon oksim) nın metal kompleksleri rapor edildi. Bütün komplekslerde Schiff bazlarının metal iyonuna imin azotu ve fenolik oksijeninden bağlanarak iki dişli şelat olarak davrandığı ve yine bütün komplekslerde M:L oranının 1:2 olduğu görüldü. $\mathrm{Co}+2, \mathrm{Ni}+2$ ve $\mathrm{Zn}+2$ komplekslerinin tetrahedral ve $\mathrm{Cu}+2$ kompleksinin ise dört koordinasyonlu yapıya sahip olduğu belirlendi. Komplekslerin $[\mathrm{M}(\mathrm{L}) 2]$ formülüne sahip oldukları bulunmuştur. Elde edilen bileşiklerin yapıları, elementel analiz, IR, 1H-NMR, 13C-NMR, Uv, manyetik süsseptibilite ve termogravimetrik analiz ile karakterize edilmiştir.
\end{abstract}

Anahtar Kelimeler: Schiff bazı, geçiş metal kompleksleri

\section{INTRODUCTION}

Schiff bases [1-6] are useful chelators because of their ease of preparation, structural varieties, varied denticities and subtle steric and electronic control on their framework. Recently a great deal of interest have developed in the synthesis and characterization of transition metal complexes containing Schiff bases as ligands due to their applications as catalysts for many reactions and relation to synthetic and natural oxygen carriers.

Schiff base compounds are readily synthesized from the condensation reaction between aldehydes and primary amines, which have been widely investigated for their biological activities, such as antibacterial, antifungal, and antitumor [7-11]. The imine $\mathrm{N}$ atom and some other donor atoms of the Schiff base compounds easily coordinate to metal atoms, forming versatile complexes [12-14].

We now report the synthesis and characterization of new tetrahedral $\mathrm{Co}(\mathrm{II}), \mathrm{Ni}(\mathrm{Il}), \mathrm{Cu}$ (II) and $\mathrm{Zn}$ (II) complexes with 5-bromo-3-methoxysalicyliden-p-iminoacetophenone oxime (LH), as well as general comparison of a tendency for tetra-coordinated structure formation in the case of $d^{7}, d^{8}, d^{9}$ and $d^{10}$ configurations. The Schiff base ligand used in this study is shown in Scheme 1. All compounds were

\footnotetext{
* Corresponding author. Email address: ecanpolat@ firat.edu.tr
} 
characterized by elemental analyses, IR, ${ }^{1} \mathrm{H}-\mathrm{NMR},{ }^{13} \mathrm{C}-\mathrm{NMR}$ spectra, UV spectra, magnetic susceptibility measurements and thermogravimetric analyses (TGA).

\section{EXPERIMENTAL}

Elemental analyses (C, H, N) were carried out using LECO-932 CHNSO by Technical and Scientific Research Council of Turkey (TUBITAK). IR spectra were recorded on a Mattson 1000 FTIR spectrometer using $\mathrm{KBr}$ pellets. ${ }^{1} \mathrm{H}$ and ${ }^{13} \mathrm{C}-\mathrm{NMR}$ spectra were taken from a Bruker $\mathrm{GmbH} \mathrm{Dpx}-400$ MHz High Performance Digital FT-NMR spectrometer. Electronic spectra were obtained on a Shimadzu 1700 UV spectrometer. Magnetic susceptibilities were measured by using a Sherwood Scientific Magnetic Susceptibility Balance(Model MK1) at room temperature using $\mathrm{Hg}\left[\mathrm{Co}(\mathrm{SCN})_{4}\right]$ as a calibrant; diamagnetic corrections were calculated from Pascal's constant. TGA curves were recorded on a Shimadzu TG-50 thermo balance.

\subsection{5-bromo-3-methoxysalicyliden-p-iminoacetophenone oxime (LH)}

A solution of $p$-aminoacetophenoneoxime $(1.50 \mathrm{~g}, 10 \mathrm{mmol})$ dissolved in $15 \mathrm{ml}$ absolute ethanol was added dropwise to 5-bromo-3-methoxysalicylaldehyde $(2.31 \mathrm{~g}, 10 \mathrm{mmol})$ and p-toluene sulfonic acid $(0.01 \mathrm{~g})$ dissolved in $35 \mathrm{ml}$ absolute ethanol under reflux at $60{ }^{\circ} \mathrm{C}$ with continuous stirring for $3 \mathrm{~h}$. Precipitate was filtered off after overnight, washed several times with hot water, cold ethanol and diethyl ether and finaly dried in vacuum.

IR spectrum (v, $\left.\mathrm{cm}^{-1}\right): 3400$ (oxime O-H), 3240 (phenolic O-H), 1625 (phenolic $\mathrm{C}=\mathrm{N}$ ), 1600 (oxime $\mathrm{C}=\mathrm{N}), 1270(\mathrm{C}-\mathrm{O}), 1005(\mathrm{~N}-\mathrm{O})$; ${ }^{1} \mathrm{H}-\mathrm{NMR}\left(\mathrm{CDCl}_{3}-\mathrm{DMSO}-d_{6}, \delta, \mathrm{ppm}\right): 14.00(\mathrm{~s}, 1 \mathrm{H}$, phenolic $\mathrm{O} \underline{\mathrm{H}})$, $11.00(\mathrm{~s}, 1 \mathrm{H}$, oxime $\mathrm{O} \underline{\mathrm{H}}), 9.39(\mathrm{~s}, 1 \mathrm{H}$, azomethine $\mathrm{C} \underline{\mathrm{H}}=\mathrm{N}), 7.68-6.82(\mathrm{~m}, 6 \mathrm{H}$ aromatic $\underline{\mathrm{H}}),, 3.74(\mathrm{~s}, 3 \mathrm{H}$, $\left.\mathrm{OC}_{3}\right), 1.90$ (s, $\left.3 \mathrm{H}, \overline{\mathrm{C}}_{3}\right) ;{ }^{13} \mathrm{C}-\mathrm{NMR}\left(\mathrm{CDCl}_{3}-\mathrm{DMSO}-d_{6}, \delta, \mathrm{ppm}\right): 164.58$ (oxime $\left.\underline{\mathrm{C}}=\mathrm{NOH}\right), 163.69$ $(\underline{\mathrm{C}} \mathrm{H}=\mathrm{N}), 162.40$ (phenolic $\underline{\mathrm{C}}-\mathrm{OH}), 156.12-116.80$ (aromatic $\underline{\mathrm{C}}), 56.30\left(\mathrm{O}_{\underline{\mathrm{C}}} \mathrm{H}_{3}\right),\left(21.81\left(\underline{\mathrm{C}} \mathrm{H}_{3}\right)\right.$.

\subsection{Bis (p-aminoacetophenoneoxime-5-bromo-3-methoxysalicylaldiminato) cobalt(II) $\mathrm{Co}(\mathrm{L})_{2}$}

A sample of the ligand $(0.36 \mathrm{~g}, 1.00 \mathrm{mmole})$ was dissolved in absolute ethanol $(25 \mathrm{~mL})$. A solution of $\mathrm{Co}(\mathrm{AcO})_{2} .4 \mathrm{H}_{2} \mathrm{O}(0.13 \mathrm{~g}, 0.50 \mathrm{mmole})$ in $15 \mathrm{~mL}$ absolute ethanol was added dropwise to the ligand solution with continuous stirring at $50{ }^{\circ} \mathrm{C}$ for $14 \mathrm{~h}$. The precipitated complex was filtered off after overnight, washed with hot $\mathrm{H}_{2} \mathrm{O}$, cold $\mathrm{EtOH}$ and cold $\mathrm{Et}_{2} \mathrm{O}$ several times and dried in vacuo.

IR spectrum (v, $\left.\mathrm{cm}^{-1}\right): 3300$ (oxime O-H), 1610 (phenolic $\left.\mathrm{C}=\mathrm{N}\right), 1599$ (oxime $\left.\mathrm{C}=\mathrm{N}\right), 1290$ (C-O), 1006 $(\mathrm{N}-\mathrm{O})$.

\subsection{Bis (paminoacetophenoneoxime-5-bromo-3-methoxysalicylaldiminato) nickel(II) $\mathrm{Ni}(\mathrm{L})_{2}$}

$\mathrm{Ni}(\mathrm{L})_{2}$ was prepared following the same procedure as described for $\mathrm{Co}(\mathrm{L})_{2}$, starting with $\mathrm{LH}(0.36 \mathrm{~g}$, 1.00 mmole $)$ and $\mathrm{Ni}(\mathrm{AcO})_{2} .4 \mathrm{H}_{2} \mathrm{O}(0.12 \mathrm{~g}, 0.50 \mathrm{mmole})$.

IR spectrum $\left(v, \mathrm{~cm}^{-1}\right): 3310$ (oxime $\left.\mathrm{O}-\mathrm{H}\right), 1615$ (phenolic $\left.\mathrm{C}=\mathrm{N}\right), 1600$ (oxime $\left.\mathrm{C}=\mathrm{N}\right), 1300(\mathrm{C}-\mathrm{O}), 1006$ $(\mathrm{N}-\mathrm{O})$.

\subsection{Bis (paminoacetophenoneoxime-5-bromo-3-methoxysalicylaldiminato) copper(II) $\mathrm{Cu}(\mathrm{L})_{2}$}

$\mathrm{Cu}(\mathrm{L})_{2}$ was prepared following the same procedure as described for $\mathrm{Co}(\mathrm{L})_{2}$, starting with $\mathrm{LH}(0.36 \mathrm{~g}$, 1.00 mmole $)$ and $\mathrm{Cu}(\mathrm{AcO})_{2} \cdot \mathrm{H}_{2} \mathrm{O}(0.13 \mathrm{~g}, 0,50$ mmole $)$.

IR spectrum (v, $\mathrm{cm}^{-1}$ ): 3290 (oxime O-H), 1610 (phenolic C=N), 1600 (oxime C=N), 1310 (C-O), 1006 $(\mathrm{N}-\mathrm{O})$.

\subsection{Bis(paminoacetophenoneoxime-5-bromo-3-methoxysalicylaldiminato) $\operatorname{zinc}(\mathrm{II}) \mathrm{Zn}(\mathrm{L})_{2}$}

$\mathrm{Zn}(\mathrm{L})_{2}$ was prepared following the same procedure as described for $\operatorname{Co}(\mathrm{L})_{2}$, starting with $\mathrm{LH}(0.36 \mathrm{~g}$, 1.00 mmole $)$ and $\mathrm{Zn}(\mathrm{AcO})_{2} .2 \mathrm{H}_{2} \mathrm{O}(0,11 \mathrm{~g}, 0,50 \mathrm{mmole})$. 
IR spectrum (v, $\mathrm{cm}^{-1}$ ): 3325 (oxime O-H), 1605 (phenolic $\mathrm{C}=\mathrm{N}$ ), 1599 (oxime $\mathrm{C}=\mathrm{N}$ ), 1295 (C-O), 1006 $(\mathrm{N}-\mathrm{O}) ;{ }^{1} \mathrm{H}-\mathrm{NMR}\left(\mathrm{CDCl}_{3}-\mathrm{DMSO}-d_{6}, \delta, \mathrm{ppm}\right): 10.99$ (s, 2H, oxime $\left.\mathrm{OH}\right), 9.13$ (s, 2H, azomethine $\mathrm{C}$ 7.70-6.80 (m, $12 \mathrm{H}$ aromatic $\underline{\mathrm{H}}$, ), $3.74\left(\mathrm{~s}, 6 \mathrm{H}, \mathrm{OCH}_{3}\right), 1.90\left(\mathrm{~s}, 6 \mathrm{H}, \mathrm{C}_{3}\right),{ }^{13} \mathrm{C}-\mathrm{NMR}\left(\mathrm{CDCl}_{3}-\mathrm{DMSO}-d_{6}\right.$, $\delta$, ppm): 164.59 (oxime $\underline{\mathrm{C}}=\mathrm{NOH}), 165.95(\underline{\mathrm{CH}}=\mathrm{N}), 165.63$ (phenolic $\underline{\mathrm{C}}-\mathrm{OH}), 156.10-116.80$ (aromatic C), $56.30\left(\mathrm{O}_{\underline{C}}{ }_{3}\right), 21.82\left(\underline{\mathrm{CH}}_{3}\right)$.

\section{RESULTS AND DISCUSSION}

The ligand (LH) was prepared by reacting equimolar amounts of 5-bromo-3methoxysalicylaldehyde with p-aminoacetophenoneoxime in absolute ethanol (scheme 1). The structures of the ligand and the complexes were established from their IR, ${ }^{1} \mathrm{H}-$ and ${ }^{13} \mathrm{C}-\mathrm{NMR}$ spectra, UV spectra, elemental analyses, magnetic susceptibility measurements and thermogravimetric analyses.

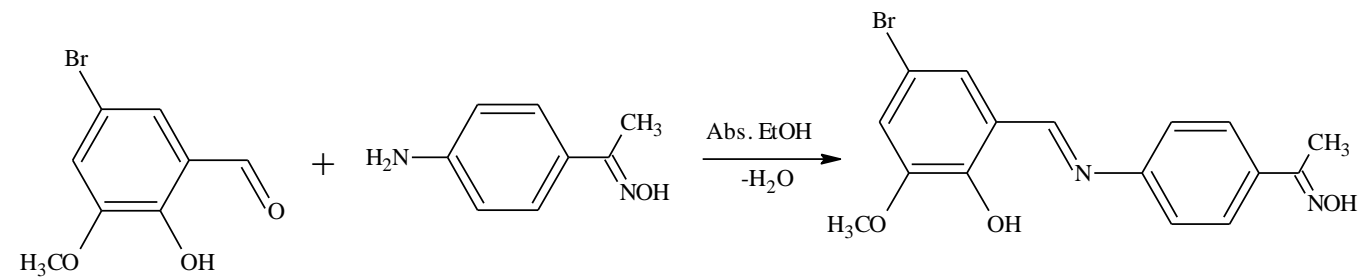

Scheme 1. Structure of the ligand.

The general equations for the formation of the complexes are shown below:

$$
\begin{aligned}
& 2 \mathrm{LH}+\mathrm{Co}\left(\mathrm{CH}_{3} \mathrm{COO}\right)_{2} \cdot 4 \mathrm{H}_{2} \mathrm{O} \rightarrow \mathrm{Co}(\mathrm{L})_{2}+2 \mathrm{CH}_{3} \mathrm{COOH}+4 \mathrm{H}_{2} \mathrm{O} \\
& 2 \mathrm{LH}+\mathrm{Ni}\left(\mathrm{CH}_{3} \mathrm{COO}\right)_{2} \cdot 4 \mathrm{H}_{2} \mathrm{O} \rightarrow \mathrm{Ni}(\mathrm{L})_{2}+2 \mathrm{CH}_{3} \mathrm{COOH}+4 \mathrm{H}_{2} \mathrm{O} \\
& 2 \mathrm{LH}+\mathrm{Cu}\left(\mathrm{CH}_{3} \mathrm{COO}\right)_{2} \cdot \mathrm{H}_{2} \mathrm{O} \rightarrow \mathrm{Cu}(\mathrm{L})_{2}+2 \mathrm{CH}_{3} \mathrm{COOH}+\mathrm{H}_{2} \mathrm{O} \\
& 2 \mathrm{LH}+\mathrm{Zn}\left(\mathrm{CH}_{3} \mathrm{COO}\right)_{2} \cdot 2 \mathrm{H}_{2} \mathrm{O} \rightarrow \mathrm{Zn}(\mathrm{L})_{2}+2 \mathrm{CH}_{3} \mathrm{COOH}+2 \mathrm{H}_{2} \mathrm{O}
\end{aligned}
$$

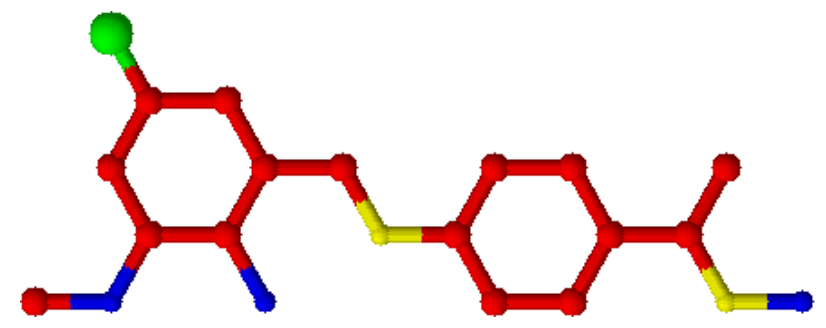

Figure 1. Conformation of ligand.

All of the metal complexes have the composition $\mathrm{M}(\mathrm{L})_{2}$ where $\mathrm{L}$ is 5-bromo-3-methoxysalicylidenp-aminoacetophenoneoxime. The analytical data are in good agreement with the proposed general molecular formula (Figure 2). 


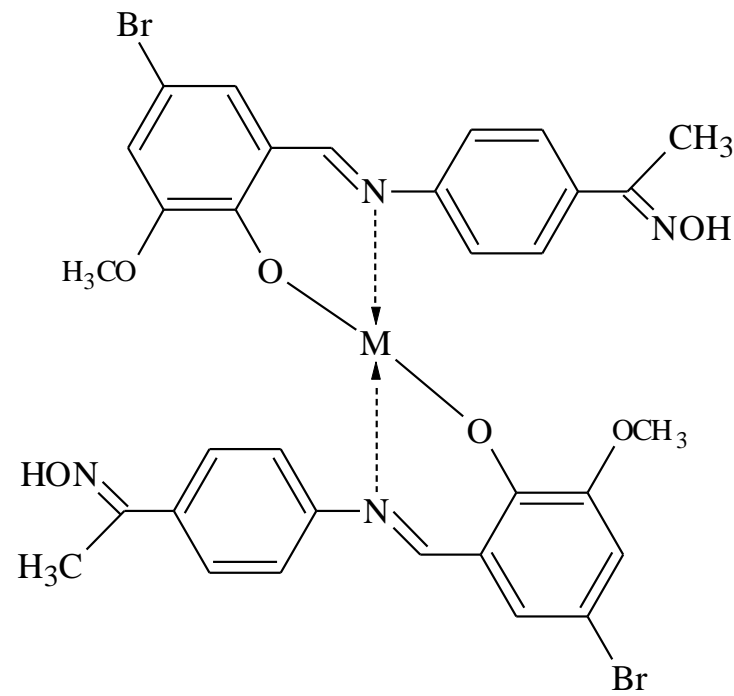

$\mathrm{M}=\mathrm{Co}(\mathrm{II}), \mathrm{Ni}(\mathrm{II}) \mathrm{Cu}(\mathrm{II})$ and $\mathrm{Zn}(\mathrm{II})$

Figure 2. Suggested structure of the tetrahedral complexes of ligand.

\subsection{Infrared Spectra}

The infrared spectrum of LH shows bands at ca. 3400, 3240, 1625, 1600, 1270 and $1005 \mathrm{~cm}^{-1}$, assigned to $\mathrm{O}-\mathrm{H}$ (oxime) [15-17], $\mathrm{O}-\mathrm{H}$ (phenolic), $\mathrm{C}=\mathrm{N}$ (azomethine), $\mathrm{C}=\mathrm{N}$ (oxime) [18-20], $\mathrm{C}-\mathrm{O}$ and $\mathrm{N}-\mathrm{O}$, respectively. These values are in agreement with those found for similar compounds [21,22]. The infrared spectral bands which are most useful for the determination of the mode of coordination of the ligand are listed in experimental section. The spectra of all metal complexes show no absorption band corresponding to $\mathrm{O}-\mathrm{H}$ (phenolic) of the aldehyde moiety. A strong band is observed in the free ligand at $1625 \mathrm{~cm}^{-1}$, characteristic of the azomethine $(\mathrm{C}=\mathrm{N})$ group [23]. Coordination of the Schiff base to the cobalt, nickel, copper and zinc ion through the azomethine nitrogen atom is expected to reduce the electron density in the azomethine link and thus lower the $(\mathrm{C}=\mathrm{N})$ absorption frequency. Hence, this band undergoes a shift to lower frequency to $1605-1615 \mathrm{~cm}^{-1}$ after complexation indicating coordination of the azomethine nitrogen [24] to cobalt, nickel, copper and zinc. A medium intensity band at $3240 \mathrm{~cm}^{-1}$ in the spectra of the free ligand due to $(\mathrm{O}-\mathrm{H})$ was absent in the spectra of all the complexes, indicating the deprotonation of Schiff base prior the coordination $[25,26]$ through its oxygen atom. This is further supported by an increase in the absorption frequency of the phenolic C-O band from $1270 \mathrm{~cm}^{-1}$ in the spectra of the free ligand to $1290-1310 \mathrm{~cm}^{-1}$ in the spectra of the complexes, indicating that the other coordination site of the Schiff base is the phenolic oxygen [27]. The practically unchanged O-H at 3400 and $\mathrm{C}=\mathrm{N}$ at $1600 \mathrm{~cm}^{-1}$ point that oxime group does not coordinate to metal atoms by neither oxygen nor nitrogen atoms. 


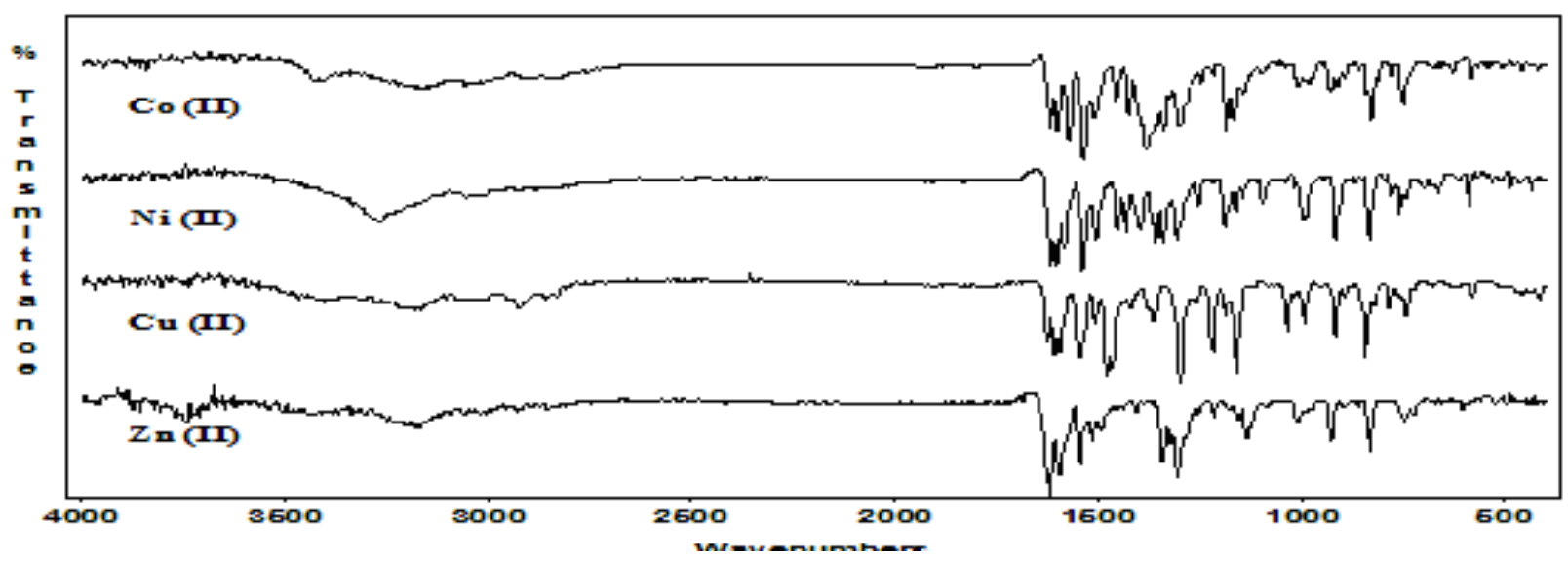

Figure 3. IR spectrum of complexes.

The NMR spectra of the Schiff base and its diamagnetic zinc(II) complex was recorded in $\mathrm{CDCl}_{3} / \mathrm{DMSO}-\mathrm{d}_{6} .{ }^{1} \mathrm{H}-$ and ${ }^{13} \mathrm{C}-\mathrm{NMR}$ assignments are detailed in experimental section. The Schiff base exhibited signals due to all the expected protons in their expected region and have been found from the integration curve equivalent to the total number of protons deduced from the proposed structure. These were compared with the reported [28] signals of the known comparable compounds and give further support for the compositions of the new ligand as well as their complexes, also suggested by their IR and elemental analyses data.

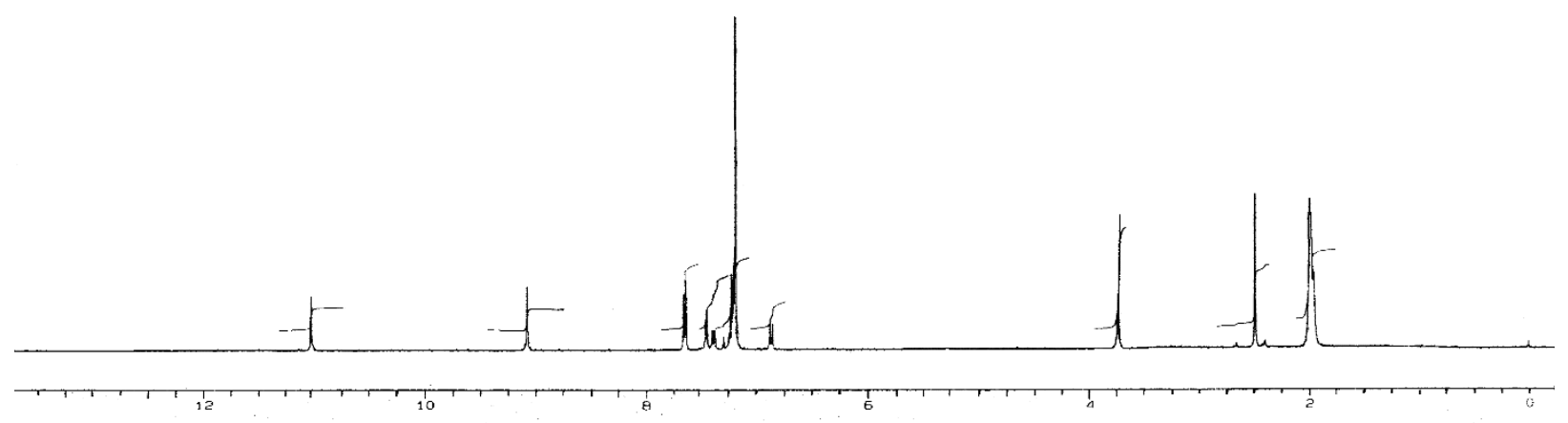

Figure 4. ${ }^{1} \mathrm{H}-\mathrm{NMR}$ spectrum of $\mathrm{Zn}$ (II) complex.

Characteristic ${ }^{1} \mathrm{H}-\mathrm{NMR}$ peaks are at 14.00 (phenolic $\mathrm{OH}$ ), 11.00 (oxime $\mathrm{OH}$ ) [16,22,28], 9.39 (azomethine $\mathrm{CH}=\mathrm{N}), 6.82-7.68\left(\right.$ Arom-H) and $1.90 \mathrm{ppm}\left(\mathrm{CH}_{3}\right)$. The phenolic $\mathrm{OH}$ signal at $14.00 \mathrm{ppm}$ disappeared upon addition of $\mathrm{D}_{2} \mathrm{O}$ to the solution, indicating that it is an acidic proton. As can be seen in the ${ }^{1} \mathrm{H}-\mathrm{NMR}$ spectra of zinc(II) complex there is no $\mathrm{OH}$ peaks expected. The signal due to azomethine group underwent an up field shift of $0.26 \mathrm{ppm}$ in the complex indicating coordination of this group with the $\mathrm{Zn}(\mathrm{II})$ ion. The absence of the phenolic $(\mathrm{O}-\mathrm{H})$ proton signal in the zinc(II) complex indicates the coordination by phenolic oxygen to the metal ion after deprotonation [29-31]. More detailed information about the structure of ligand was provided by ${ }^{13} \mathrm{C}-\mathrm{NMR}$ spectral data $\mathrm{CH}=\mathrm{N}$ and $\mathrm{C}-\mathrm{OH}$ carbon atoms are observed at 163.69 and $162.40 \mathrm{ppm}$ respectively for Schiff base. ${ }^{13} \mathrm{C}-\mathrm{NMR}$ spectrum of zinc(II) complex $\mathrm{CH}=\mathrm{N}$ and $\mathrm{C}-\mathrm{OH}$ carbon atoms are observed at 165.95 and $165.63 \mathrm{ppm}$ respectively. The rest of carbon atoms, likewise showed similar diagnostic features for the free ligand as well as its complex as expected. The signals corresponding to the $\mathrm{O}-\mathrm{H}$ proton and $\mathrm{C}=\mathrm{N}-\mathrm{OH}$ carbon, (both in oxime groups) are unchanged in the ${ }^{1} \mathrm{H}$ - and ${ }^{13} \mathrm{C}-\mathrm{NMR}$ spectra of the complexes indicating that these oxime groups do not take part in complexation. 
Table 1. Analytical and physical data of the ligand and the complexes.

\begin{tabular}{|c|c|c|c|c|c|c|c|c|}
\hline \multirow[t]{2}{*}{ Compounds } & \multirow[t]{2}{*}{ Formula } & \multirow{2}{*}{$\begin{array}{c}\text { F.W } \\
(\mathrm{g} / \mathrm{mol})\end{array}$} & \multirow[t]{2}{*}{ Color } & \multirow{2}{*}{$\begin{array}{l}\text { Yield } \\
(\%)\end{array}$} & \multirow{2}{*}{$\begin{array}{c}\mu_{\mathrm{eff}} \\
\text { (B.M.) }\end{array}$} & \multicolumn{3}{|c|}{$\begin{array}{l}\text { Elemental analysis } \\
\text { ulated (found) }(\%)\end{array}$} \\
\hline & & & & & & $\mathrm{C}$ & $\mathrm{H}$ & $\mathrm{N}$ \\
\hline LH & $\mathrm{C}_{16} \mathrm{H}_{15} \mathrm{BrN}_{2} \mathrm{O}_{3}$ & 363.21 & yellow & 80 & - & $\begin{array}{c}52.91 \\
(53.30)\end{array}$ & $\begin{array}{c}4.16 \\
(3.79)\end{array}$ & $\begin{array}{c}7.71 \\
(8.08)\end{array}$ \\
\hline $\mathrm{Co}(\mathrm{L})_{2}$ & $\mathrm{CoC}_{32} \mathrm{H}_{28} \mathrm{Br}_{2} \mathrm{~N}_{4} \mathrm{O}_{6}$ & 783.33 & brown & 55 & 4.15 & $\begin{array}{c}49.07 \\
(48.71)\end{array}$ & $\begin{array}{c}3.60 \\
(3.33)\end{array}$ & $\begin{array}{c}7.15 \\
(6.85)\end{array}$ \\
\hline $\mathrm{Ni}(\mathrm{L})_{2}$ & $\mathrm{NiC}_{32} \mathrm{H}_{28} \mathrm{Br}_{2} \mathrm{~N}_{4} \mathrm{O}_{6}$ & 783.09 & green & 59 & 2.91 & $\begin{array}{c}49.08 \\
(48.77)\end{array}$ & $\begin{array}{c}3.60 \\
(3.36)\end{array}$ & $\begin{array}{c}7.15 \\
(6.80)\end{array}$ \\
\hline $\mathrm{Cu}(\mathrm{L})_{2}$ & $\mathrm{CuC}_{32} \mathrm{H}_{28} \mathrm{Br}_{2} \mathrm{~N}_{4} \mathrm{O}_{6}$ & 787.94 & light red & 51 & 1.83 & $\begin{array}{r}48.78 \\
(49.16)\end{array}$ & $\begin{array}{c}3.60 \\
(3.20)\end{array}$ & $\begin{array}{c}7.15 \\
(6.76)\end{array}$ \\
\hline $\mathrm{Zn}(\mathrm{L})_{2}$ & $\mathrm{ZnC}_{32} \mathrm{H}_{28} \mathrm{Br}_{2} \mathrm{~N}_{4} \mathrm{O}_{6}$ & 789.80 & orange & 63 & dia & $\begin{array}{r}48.66 \\
(49.01)\end{array}$ & $\begin{array}{c}3.57 \\
(3.97)\end{array}$ & $\begin{array}{c}7.09 \\
(6.74)\end{array}$ \\
\hline
\end{tabular}

The general characteristic properties of the complexes and the Schiff base are shown in Table 1. The elemental analysis results agree with the calculated values showing that the complexes have 1:2 metal/ligand ratios. The elemental analysis confirmed the compositions of the above synthesized compounds.

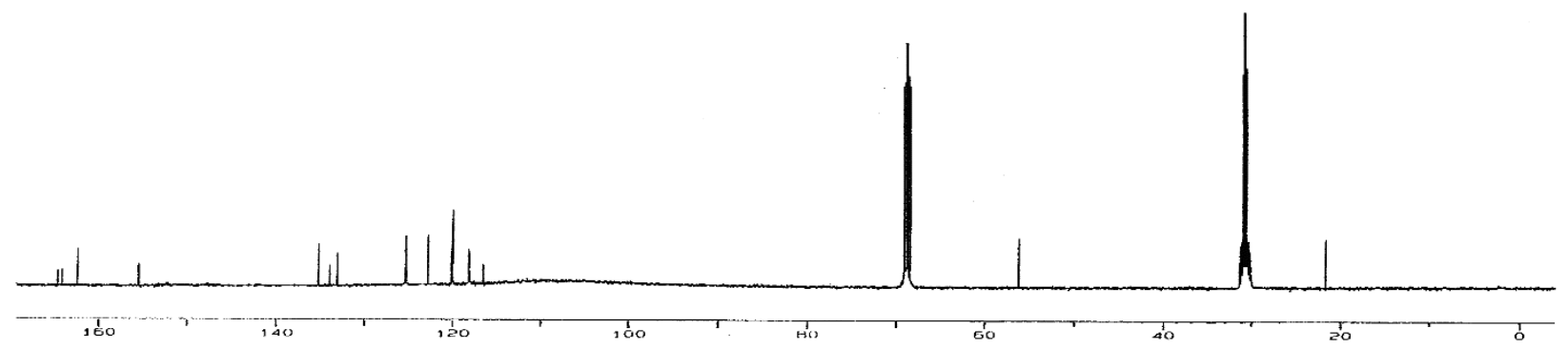

Figure 5. ${ }^{13} \mathrm{C}-\mathrm{NMR}$ spectrum of $\mathrm{Zn}$ (II) complex.

The room temperature magnetic moment values of the complexes are given in Table 1. The magnetic moment value of 4.15 B.M. measured for the cobalt complex lies in the range expected for a $d^{7}$ system, which contains one unpaired electron with tetrahedral geometry [32]. The measured value of 2.91 B.M. for the nickel complex suggests tetrahedral geometry for this complex [33]. The observed magnetic moment of 1.83 B.M. is consistent with a four coordinated copper(II) complex [34]. The zinc(Il) complex was found to be diamagnetic as expected. The electronic spectra of the Schiff base and all the complexes were recorded in DMF at room temperature. The electronic spectral data of the ligand and its complexes are given in experimental section. The aromatic band of the ligand at $275 \mathrm{~nm}$ is attributed to benzene $\pi \rightarrow \pi^{*}$ transition. The band around $390 \mathrm{~nm}$ is due to the $n \rightarrow \pi^{*}$ transition of the non-bonding electrons present on nitrogen of the azomethine group in the Schiff base. The complexes of cobalt(II), nickel(II) and copper(II) show less intense shoulders at $c a$. 560-670 nm $(\varepsilon=155-190 \mathrm{~L}$ $\mathrm{mol}^{-1} \mathrm{~cm}^{-1}$ ), which are assigned as $d-d$ transition of the metal ions. The former band is probably due to the ${ }^{4} \mathrm{~A}_{2} \rightarrow{ }^{4} \mathrm{~T}_{1}$ (P) for $\mathrm{Co}(\mathrm{II}),{ }^{3} \mathrm{~A}_{2} \rightarrow{ }^{3} \mathrm{~T}_{2}$ (F) for $\mathrm{Ni}(\mathrm{II})$ and ${ }^{2} \mathrm{~T}_{2} \rightarrow{ }^{2} \mathrm{E}$ (G) for $\mathrm{Cu}(\mathrm{II})$ transition of tetrahedral 
geometry. All the complexes show an intense band at $c a$ 370-394 nm which is assigned to $n \rightarrow \pi^{*}$ transition associated with azomethine linkage. The spectra of all the complexes show intense band at $c a$ $425-440 \mathrm{~nm}\left(\varepsilon=1.50-4.00 \times 10^{3} \mathrm{~L} \mathrm{~mol}^{-1} \mathrm{~cm}^{11}\right)$, which can be assigned to charge transfer transition of tetrahedral geometry [35-37].

The thermogravimetric (TG) curves for the complexes were obtained at a heating rate of $10^{\circ} \mathrm{C} / \mathrm{min}$ and a $30 \mathrm{~mL} / \mathrm{min}$ flowing nitrogen over a temperature range of $20-800^{\circ} \mathrm{C}$. Approximately $10 \mathrm{mg}$ samples of the complexes were used in each case. The TG curves showed that the thermal decomposition of the complexes takes place in two steps. Furthermore, it is known that the electronegativity and the atomic radius of the central metal atom also affect the thermal stability [38]. Thermogravimetric studies of all the complexes showed no weight loss up to $205{ }^{\circ} \mathrm{C}$ indicating absence of water in the complexes. The inflation of the TG curves of all the complexes at a temperature under $720{ }^{\circ} \mathrm{C}$ indicates the decomposition of the fully organic part of the chelate, leaving metallic oxide at the final temperature [39,40]. The thermal stability of all complexes increases in the order: $\mathrm{Cu}<\mathrm{Zn}<\mathrm{Ni}<\mathrm{Co}$.

\section{CONCLUSION}

Our group has been heavily engaged in synthesis of substituted oximes and their Schiff-base derivatives. Many Schiff-base derivatives, containing substituted oximes, were synthesized, characterized in detail and used for complexation with some transition metal salts. Functional groups, such as oxime, on the complexes have no effect. These functional groups are very far from the pendants taking part in the complexation. The Schiff-base ligand and its $\mathrm{Co}(\mathrm{II}), \mathrm{Ni}(\mathrm{II}), \mathrm{Cu}(\mathrm{II})$ and $\mathrm{Zn}$ (II) metal complexes were synthesized and characterized by elemental analyses, IR, ${ }^{1} \mathrm{H}$ - and ${ }^{13} \mathrm{C}-\mathrm{NMR}$ spectra, Uv spectra, magnetic susceptibility measurements and thermogravimetric analyses (TGA). All complexes are mononuclear and tetrahedral. According to results obtained from TGA, IR and elemental analyses, there are no lattice/coordinated water molecules in the complexes. For these complexes, additional analytical and physical data are given in Table 1 . The suggested modes of coordination are shown in Figure 2.

\section{Acknowledgements}

This work was supported by the Management Unit of Scientific Research Projects of Frrat University (Project No: FÜBAP 1834).

\section{REFERENCES}

[1] Alexander A., Design and synthesis of macrocyclic ligands and their complexes of lanthanides and actinides. Chem Rev 1995; 95: 273-342

[2] Vigato P.A., Tamburini S., Bertolo L., The development of compartmental macrocyclic Schiff bases and related polyamine derivatives. Coord Chem Rev 2007; 251: 1311-1492

[3] Quiruga A.G., Ranninger C.N., Contribution to the SAR field of metallated and coordination complexes: Studies of the palladium and platinum derivatives with selected thiosemicarbazones as antitumoral drugs. Coord Chem Rev 2004; 248: 119-133.

[4] West D.X., Liberta A.E., Padhye S.B., Chikate R.C., Sonawane P.B., Kumbhar A.S., Yerande R.G., Thiosemicarbazone complexes of copper(II): structural and biological studies. Coord Chem Rev 1993; 123: 49-71.

[5] Rai B.K., Kumari R., Synthesis, structural, spectroscopic and antibacterial studies of schiff base ligands and their metal complexes containing nitrogen and sulphur donor atomantixancer. Oriental J Chem 2013; 29: 1163-1167.

[6] Lobana T.S., Sharma R., Bawa G., Khanna S., Bonding and structure trends of thiosemicarbazone derivatives of metals-an overview. Coord Chem Rev 2009; 253: 977-1055.

[7] Ugras H.I., Basaran I., Kilic T., Cakir U., Synthesis, complexation and antifungal, antibacterial activity studies of a new macrocyclic schiff base. J Het Chem 2006; 43: 1679-1684. 
[8] Shi L., Ge Hui-M., Tan Shu-H., Li Huan-Qiu., Song Yong-C., Zhu Hai-L., Synthesis and antimicrobial activities of Schiff bases derived from 5-chloro-salicylaldehyde. Eur J Med Chem 2007; 42: 558-564.

[9] Dilmaghani K.A., Jazani N.H., Behrouz A., Fakhraee F.M., Synthesis, characterization and antibacterial activity of some schiff bases derived from 4-aminobenzoic acid. Asian J Chem 2009; 21: 5947-5954.

[10] Hearn M.J., Cynamon, M.H., Chen M.F., Coppins R., Davis J., Kang HJ-On., Noble A., Tu-Sekine B., Terrot M.S., Trombino D., Thai M., Webster E.R., Wilson R., Preparation and antitubercular activities in vitro and in vivo of novel schiff bases of isoniazid. Eur J Med Chem 2009; 44: 41694178.

[11] Saghatforoush L.A., Chalabian F., Aminkhani A., Karimnezhad G., Ershad S., Synthesis, spectroscopic characterization and antibacterial activity of new cobalt(II) complexes of unsymmetrical tetradentate (OSN2) schiff base ligands. Eur Med Chem 2009; 44: 4490-4495.

[12] Yaftian M.R., Rayati S., Safarbali R., Torabi N., Khavasi H.R., A new tetradentate N2O2-type Schiff base ligand. Synthesis, extractive properties towards transition metal ions and X-ray crystal structure of its nickel complex. Trans Met Chem 2007; 32: 374-378.

[13] Salehzadeh S., Golbedaghi R., Khavasi., H.R., Synthesis, characterization, and crystal structure of a $\mathrm{Ni}(\mathrm{II})$ complex of an acyclic pentadentate schiff base; an agreement between the experimental and theoretical results. J Coord Chem 2009; 62: 2532-2539.

[14] Zhang Chen-X., Cui C., Lu M., Yu L., Zhan Yue-X., In situ synthesis, characterization and crystal structure of a novel cobalt(III) complex with tridentate schiff base. Synth React Inorg Met-Org Nano-Met Chem 2009; 39: 136-138.

[15] Ramesh R., Sivagamasundari M., Synthesis, spectral and antifungal activity of Ru(II) mixed-ligand complexes. Synth React Inorg Met-Org Nano-Met Chem 2003; 33: 899-910.

[16] Tuna S., Canpolat E., Kaya M., Synthesis and characterization of a new 4-methoxysalicyliden-paminoacetophenoneoxime and its complexes with $\mathrm{Co}(\mathrm{II}), \mathrm{Ni}(\mathrm{II}), \mathrm{Cu}(\mathrm{II})$ and $\mathrm{Zn}(\mathrm{II})$. Polish J Chem 2006; 80: 1651-1656.

[17] Canpolat E., Şahal H., Kaya M., Gür S., Synthesis, characterization antibacterial and antifungal activities studies of copper(II), cobalt(II) and zinc(II) complexes of the schiff base ligand derived from 4,4-diaminodiphenylether. J Chem Soc Pakistan 2014; 36: 106-112.

[18] Saxena A., Tandon J.P., Structural features of some organotin(IV) complexes of semi-and thiosemicarbazones. Polyhedron 1984; 3: 681-688.

[19] Kukushkin Y.N., Krylov V.K., Kaplan S.F., Calligaris M., Zangrando E., Pombeiro A.J.L., Kukushkin V.Y., Different chlorination modes of oximes: chlorination of salicylaldoxime coordinated to platinum. Inorg Chim Acta 1999; 285: 116-121.

[20] Bakırdere E.G., Canpolat E., Kaya M., Gür N., Synthesis, antibacterial and antifungal activity of a new 2-\{(e)-[(4-aminophenyl) 1mino]methyl $\}$-6-methoxy-4-nitrophenol and its complexes with Co(II), Ni(II), Cu(II) and Zn(II). J Chem Soc Pakistan 2012; 34: 1186-1190.

[21] Satapathy S., Sahoo B., Salicylaldazinate metal chelates and their I.R. spectra. J Inorg Nucl Chem 1970; 32: 2223-2227.

[22] Canpolat E., Studies on mononuclear chelates derived from substituted schiff bases ligands (part 8): synthesis and characterization of a new 5-chlorosalicyliden-p-aminoacetophenoneoxime and its complexes with $\mathrm{Co}(\mathrm{II}), \mathrm{Ni}(\mathrm{II}), \mathrm{Cu}(\mathrm{II})$ and $\mathrm{Zn}(\mathrm{II})$. Polish J Chem 2005; 79: 619-625.

[23] Khera B., Sharma A.K., Kaushik N.K., Bis(indenyl)titanium(IV) and zirconium(IV) complexes of monofunctional bidentate salicylidimines. Polyhedron 1983; 2: 1177-1180.

[24] Maurya R.C., Patel P., Rajput S., Synthesis and characterization of n-(o-vanillinidene)-p-anisidine and N,N'-bis(o-vanillinidene)ethylenediamine and their metal complexes. Synth React Inorg MetOrg Nano-Met Chem 2003; 33: 817-836. 
[25] Bamfield P., The reaction of cobalt halides with N-arylsalicylideneimines. J Chem Soc A: Inorg Phys Theor 1967; 804-808.

[26] Canpolat E., Kaya M., Studies on mononuclear chelates derived from substituted schiff bases ligands: synthesis and characterization of a new 5-methoxysalicyliden-p-aminoacetophenoneoxime and its complexes with $\mathrm{Co}(\mathrm{II}), \mathrm{Ni}(\mathrm{II}), \mathrm{Cu}(\mathrm{II})$ and $\mathrm{Zn}$ (II). Russian J Coord Chem 2005; 31: 790-794.

[27] Boucher L.J., Manganese schiff's base complexes-II: Synthesis and spectroscopy of chlorocomplexes of some derivatives of (salicylaldehydeethylenediimato) manganese(III). J lnorg Nucl Chem 1974; 36: 531-536.

[28] Canpolat E., Kaya M., Studies on mononuclear chelates derived from substituted schiff bases ligands (part 4): synthesis and characterization of a new 5-hydroxysalicyliden-paminoacetophenoneoxime and its complexes with $\mathrm{Co}(\mathrm{II}), \mathrm{Ni}(\mathrm{II}), \mathrm{Cu}(\mathrm{II})$ and $\mathrm{Zn}$ (II). Turkish J Chem 2005; 29: 409-415.

[29] Nour E.M., Taha A.A., Alnaimi I.S., Infrared and Raman studies of [UO2(salen)(L)] (L=H2O and CH3OH). Inorg Chem Acta 1988; 141: 139-144.

[30] Agarwala B.V., Hingorani S., Puri V., Khetrapal C.L., Naganagowda G.A., Physicochemical studies of (o-vanillin thiosemicarbazonato)-nickel(II) chelate. Trans Met Chem 1994; 19: 25-27.

[31] Canpolat E., Yazıcı A., Kaya M., Studies on mononuclear chelates derived from substituted schiffbase ligands (part 10): synthesis and characterization of a new 4-hydroxysalicyliden-paminoacetophenoneoxime and its complexes with $\mathrm{Co}(\mathrm{II}) \mathrm{Ni}(\mathrm{II}), \mathrm{Cu}(\mathrm{II})$ and $\mathrm{Zn}$ (II). J Coord Chem 2007; 60: 473-480.

[32] Panda P.K., Mishra S.B., Mohapatra B.K. Complexes of cobalt(II), nickel(II), copper(II) and zinc(II) with dicyanadiamide. J lnorg Nucl Chem 1980; 42: 497-499.

[33] West D.X., Nassar A.A., El-Saied F.A., Ayad M.I., Copper(II) complexes of 2-aminoacetophenone N(4)-substituted thiosemicarbazones. Trans Met Chem 1998; 23: 321-325.

[34] Aboaly M.M., Khalil M.M.H., Synthesis and spectroscopic study of $\mathrm{Cu}(\mathrm{II}), \mathrm{Ni}(\mathrm{II})$, and $\mathrm{Co}(\mathrm{II})$ complexes of the ligand salicylidene-2-amino thiophenol. Spectr Lett 2001; 34: 495-504.

[35] Yamada S., Takeuchi A., The conformation and interconversion of schiff base complexes of nickel(II) and copper(II). Coord Chem Rev 1982; 43: 187-204.

[36] Wagner M.R., Walker F.A., Spectroscopic study of 1:1 copper(II) complexes with schiff base ligands derived from salicylaldehyde and L-histidine and its analogs. Inorg Chem 1983; 22: 30213028.

[37] Atkins R., Brewer G., Kokot E., Mockler G.M., Sinn E., Copper(II) and nickel(II) complexes of unsymmetrical tetradentate schiff base ligands. Inorg Chem 1985;. 24: 127-134.

[38] Brzyska W., Krol A., Properties and thermal decomposition in air atmosphere of $\mathrm{Co}(\mathrm{II}), \mathrm{Ni}(\mathrm{II})$, $\mathrm{Cu}$ (II) and $\mathrm{Zn}$ (II) benzene-1,2-dioxyacetates. Therm Acta 1993; 223: 241-249.

[39] Li S-Lan., Liu D-Xin., Zhang S-Qiang., Wang H., Yang Z-He., Determination of mechanism functions and kinetic parameters of thermodecomposition of complexes with the schiff base derived from 3-methoxysalicylaldehyde and diamine with non-isothermal TG and DTG curves. Therm Acta 1996;. 275: 215-224.

[40] El-Bindary A.A, El-Sonbati A.Z., Synthesis and properties of complexes of copper(II), nickel(II), cobalt(II) and uranyl ions with 3-(p-tolylsulphonamido)rhodanine. Polish J Chem 2000; 74: 615620. 